\title{
Metagenomic Investigation of a Low Diversity, High Salinity Offshore Oil Reservoir
}

\author{
Gabrielle Scheffer ${ }^{1}$ (D, Casey R. J. Hubert ${ }^{1,2, *}$, Dennis R. Enning ${ }^{3}$, Sven Lahme ${ }^{2,4}$, Jaspreet Mand ${ }^{4}$ (D) \\ and Júlia R. de Rezende 2,5 (iD
}

1 Department of Biological Sciences, University of Calgary, Calgary, AB T2N 1N4, Canada; gabrielle.scheffe1@ucalgary.ca

2 School of Natural and Environmental Sciences, Newcastle University, Newcastle upon Tyne NE1 7RU, UK; sven.a.lahme@exxonmobil.com (S.L.); j.de.rezende@hw.ac.uk (J.R.d.R.)

3 Faculty of Life Sciences and Technology, Berlin University of Applied Sciences and Technology, D-13347 Berlin, Germany; dennis.enning@bht-berlin.de

4 Exxon Mobil Upstream Research Company, Spring, TX 77389, USA; jaspreet.mand@exxonmobil.com

5 The Lyell Centre, Heriot-Watt University, Edinburgh EH14 4AS, UK

* Correspondence: chubert@ucalgary.ca

Citation: Scheffer, G.; Hubert, C.R.J.; Enning, D.R.; Lahme, S.; Mand, J.; de Rezende, J.R. Metagenomic Investigation of a Low Diversity, High Salinity Offshore Oil Reservoir. Microorganisms 2021, 9, 2266.

https://doi.org/10.3390/

microorganisms 9112266

Academic Editor: Tamara N. Nazina

Received: 16 August 2021

Accepted: 28 September 2021

Published: 31 October 2021

Publisher's Note: MDPI stays neutral with regard to jurisdictional claims in published maps and institutional affiliations.

Copyright: (c) 2021 by the authors. Licensee MDPI, Basel, Switzerland. This article is an open access article distributed under the terms and conditions of the Creative Commons Attribution (CC BY) license (https:// creativecommons.org/licenses/by/ $4.0 /)$.

\begin{abstract}
Oil reservoirs can represent extreme environments for microbial life due to low water availability, high salinity, high pressure and naturally occurring radionuclides. This study investigated the microbiome of saline formation water samples from a Gulf of Mexico oil reservoir. Metagenomic analysis and associated anaerobic enrichment cultures enabled investigations into metabolic potential for microbial activity and persistence in this environment given its high salinity (4.5\%) and low nutrient availability. Preliminary $16 S$ rRNA gene amplicon sequencing revealed very low microbial diversity. Accordingly, deep shotgun sequencing resulted in nine metagenome-assembled genomes (MAGs), including members of novel lineages QPJE01 (genus level) within the Halanaerobiaceae, and BM520 (family level) within the Bacteroidales. Genomes of the nine organisms included respiratory pathways such as nitrate reduction (in Arhodomonas, Flexistipes, Geotoga and Marinobacter MAGs) and thiosulfate reduction (in Arhodomonas, Flexistipes and Geotoga MAGs). Genomic evidence for adaptation to high salinity, withstanding radioactivity, and metal acquisition was also observed in different MAGs, possibly explaining their occurrence in this extreme habitat. Other metabolic features included the potential for quorum sensing and biofilm formation, and genes for forming endospores in some cases. Understanding the microbiomes of deep biosphere environments sheds light on the capabilities of uncultivated subsurface microorganisms and their potential roles in subsurface settings, including during oil recovery operations.
\end{abstract}

Keywords: Gulf of Mexico; marine subsurface; formation water; polyextremophiles; microbial adaptation; microbial persistence; metagenomics; halophiles; radionuclide resistance; metal acquisition

\section{Introduction}

Microorganisms are found in virtually all environments and have adapted to withstand a wide range of conditions in terms of $\mathrm{pH}$, pressure, temperature, radiation, salinity, water content and nutrient availability [1-4]. These abiotic factors govern essential parameters that are known to constrain microbial life, such as the presence of a solvent (water), a source of energy (substrate) and a redox potential for respiration [2].

Oil reservoirs are considered extreme environments where organisms may require adaptations to high toxicity, low water availability, high temperature, high salinity, high pressure and exposure to radioactivity $[5,6]$. Nutrients and electron acceptors are limited, and may be inaccessible to planktonic microorganisms [5]. In deep oil reservoirs, dissolved oxygen or nitrate are normally absent as electron acceptors unless introduced during engineering interventions associated with oil recovery $[5,7]$. Iron and manganese are 
not normally in a bioavailable form for respiration. The most prevalent processes are therefore fermentation and methanogenesis [8]. Sulfate reduction can become relevant and problematic during secondary oil recovery when this electron acceptor is introduced in large quantities into the reservoir through the injection of seawater [5].

Deep biosphere microorganisms can be of practical interest, as these microorganisms may impact oil industry operations through souring and microbial corrosion [5,9], phenomena which are difficult to control over prolonged periods of time [10]. Other microorganisms can mitigate these negative effects, e.g., by utilizing injected nitrate as an electron acceptor. However, research into microbial processes like souring and souring control under hypersaline conditions is limited [11,12]. This study aimed to characterize the genomic potential of microorganisms from a deep biosphere hypersaline formation water in the Gulf of Mexico to better understand biological adaptations in a low nutrient, low electron acceptor, hypersaline environment. This is relevant for advancing knowledge of how microorganisms can impact subsurface oil operations, and in considering boundary conditions in extreme environments that determine the limits to microbial life [13].

\section{Materials and Methods}

\subsection{Source of Formation Water}

Water was collected from the oil-water separation system on an offshore platform producing oil and sweet gas $\left(\mathrm{no}_{2} \mathrm{~S}\right)$ from a moderately high temperature reservoir $\left(52{ }^{\circ} \mathrm{C}\right)$ in the Gulf of Mexico. This highly saline water can be considered original formation water as the offshore asset does not use seawater injection for secondary oil recovery, i.e., no external water is injected into the reservoir. In addition, no biocides or corrosion inhibitors had been applied. A brand new 5-gallon steel drum with an internal polytetrafluoroethylene (PTFE) liner was rinsed with deionized water and then flushed with the same produced water being sampled prior to being filled to the brim with the anoxic water and capped. This sample was shipped to shore at ambient temperature and arrived in a laboratory in Texas, USA, 14 days later. Using anoxic and aseptic technique the water was transferred into sterile $2 \mathrm{~L}$ glass bottles under an atmosphere of $21 \% \mathrm{CO}_{2}\left(\right.$ balance $\left.\mathrm{N}_{2}\right)$ that were capped with butyl rubber stoppers. The water was then shipped to Newcastle University, UK, where it was received within three weeks and stored at $4{ }^{\circ} \mathrm{C}$ upon receipt. Within 5 days, $10 \mathrm{~mL}$ samples were filtered onto a sterile autoclaved $0.2 \mu \mathrm{m}$ polycarbonate membrane filter (Whatman, UK) and frozen at $-80^{\circ} \mathrm{C}$ for DNA extraction.

Additional water samples for DNA extraction were obtained from two anoxic enrichments of the formation water. One enrichment was amended with acetate $(5 \mathrm{mM})$, propionate $(0.5 \mathrm{mM})$, butyrate $(0.5 \mathrm{mM})$, bicarbonate $(20 \mathrm{mM})$, nitrate $(4 \mathrm{mM})$ and sulfate ( $3 \mathrm{mM})$; the sulfate was completely precipitated as $\mathrm{BaSO}_{4}$ owing to an excess of barium in the produced water. The other enrichment was left unamended, consisting only of $150 \mathrm{~mL}$ of the formation water in an anoxic, sealed serum bottle. Incubations were performed at $30{ }^{\circ} \mathrm{C}$, and after 247 days a $10 \mathrm{~mL}$ aliquot was removed and frozen at $-80{ }^{\circ} \mathrm{C}$ for DNA extraction. Both enrichments contained mild steel coupons (less than $0.002 \mathrm{~mm} / \mathrm{y}$ corrosion was measured, and is not the focus of the present study).

\subsection{Water Analysis}

Formation water samples for geochemical analyses were taken during field collection and upon arrival at the Texas laboratory. Analyses were performed by Intertek (Houston, TX, USA; Supplementary Material File S1). Concentrations of anions and organic acids were measured by ion chromatography using a Dionex ICS (Thermo Scientific, Waltham, MA, USA). Concentrations of $\mathrm{Al}, \mathrm{Ba}, \mathrm{B}, \mathrm{Cd}, \mathrm{Ca}, \mathrm{Cr}, \mathrm{Cu}, \mathrm{Fe}, \mathrm{Pb}, \mathrm{Li}, \mathrm{Mg}, \mathrm{Mn}, \mathrm{Ni}, \mathrm{P}, \mathrm{K}, \mathrm{Si}, \mathrm{Na}$, $\mathrm{Sr}$ and $\mathrm{Zn}$ were determined using inductively coupled plasma spectroscopy.

\subsection{DNA Extraction, $16 S$ rRNA Gene Sequencing and Analysis}

DNA from the formation water and the two enrichment incubations was extracted using the MoBio Powersoil DNA Isolation kit (MO BIO, Carlsbad, CA, USA). A clean (unused) 
$0.2 \mu \mathrm{m}$ polycarbonate membrane filter was used as a negative control for the extractions. DNA extracts were first used for 16S rRNA gene amplification (30 cycles) and sequencing on an Ion Personal Genome Machine (Ion Torrent, Life Technologies, Paisley, UK), using primers F515 and R926 [14] and procedures as described previously [15]. A fastq file was generated and further analyses were conducted with mothur [16] software, version 1.39.5. Reads were initially trimmed using trim.seqs with the following parameters: maxambig $=0$, maxhomop $=6$, bdiffs $=0$, pdiffs $=0$, minlength $=200$, keepfirst $=400$, flip $=$ F. Further data processing and analyses based on operational taxonomic units (OTUs) followed guidelines available at http://mothur.org/wiki/454_SOP [17] (accessed on 1 December 2017) with minor modifications. OTUs were defined as sequences sharing $97 \%$ identity. Taxonomic assignment from mothur was further confirmed for representative sequences through the RDP Naïve Bayesian rRNA Classifier version 2.11 [18] using the RDP 16S rRNA training set No 18 (July 2020). All raw sequence data files (fastq format) generated in this study are available through the NCBI Sequence Read Archive (Bio-Project accession number PRJNA752507).

\subsection{Metagenomics}

\subsubsection{Metagenome Sequencing}

To maximize DNA template input for shotgun metagenomic sequencing, additional aliquots of the original formation water (total $90 \mathrm{~mL}$ ) and the enrichments (total $30 \mathrm{~mL}$ ) were filtered. DNA was extracted as described above and combined with remaining DNA from the extracts used for amplicon sequencing. DNA amounts derived from the original formation water, the amended and the unamended enrichments were determined using a Qubit dsDNA HS Assay Kit (Life Technologies, Paisley, UK) as being 170, 35 and 44 ng, respectively. Metagenomic sequencing was carried out by NU-OMICS (Northumbria University, Newcastle upon Tyne, UK) using the Nextera XT library preparation kit following manufacturer's instructions. Libraries were diluted to a final concentration of $8 \mathrm{pM}$ and sequenced using a V3 600 cycle kit on an Illumina MiSeq platform.

\subsubsection{Processing of Metagenome-Assembled Genomes (MAGs)}

BBDuk was used for quality control of the reads [19]. The last $151 \mathrm{bp}$ of the reads and the partial adapters were trimmed off, contaminants were filtered out, low quality ends were removed and FastQC was used to evaluate sequence quality $[19,20]$. To increase the likelihood of resolving high quality MAGs, co-assembly was performed on the three samples used in this study. Megahit was used for co-assembly and the kmax value was set to be longer than the size of the median sample to improve quality. Bowtie2 was used for mapping the fasta files with new simple definitions to enable further processing of mapping files in Anvi'o [21,22]. Fasta files were then sorted and indexed using SAMtools [23]. For binning, Metabat was used, and MAGs 1, 3 and 7 were imported to Anvi'o for refinement $[21,24]$. MAGs that were at least $50 \%$ complete with less than $10 \%$ redundancy were retained for further investigation. CheckM and GTDB-Tk were used to assess MAG quality and assign taxonomy [24-26]. Annotation was performed using DRAM [27].

\subsubsection{Metabolic Predictions}

Gene annotations were confirmed by verifying protein functions using the Kyoto Encyclopedia of Genes and Genomes (KEGG) [28]. To investigate salt adaptation, gene lists from Daly et al. [29] were used as a guide. DetR DB was used to look for radiation resistance genes [30]. To assess endosporulation potential, 237 genes listed in Jones et al. [31] were used as a guide. BlastP alignments of proteins with $>30 \%$ identity, a bit score over 50 and an E-value lower than $1 \times 10^{-3}$ were considered matches for MAGs 6 and 7 [32]. Information on retrieved genes from any database is available in Supplementary Material File S2. 


\subsubsection{Phylogeny}

Phylogenetic trees were constructed using CheckM version 1.1.3 [25] and included 2052 finished and 3604 draft genomes obtained from the Integrated Microbial Genomes (IMG) database. Genes were aligned under GAMMA and WAG models [25]. Nodes were interpreted as bootstrap values and the tree was built using Dendroscope for visualization $[25,33]$.

\section{Results and Discussion}

\subsection{Formation Water Chemistry}

Common anions and cations were measured within the formation water samples. Concentrations of sulfate, nitrate, nitrite and most organic acids were below the limits of detection (Supplementary Material File S1). The acetate concentration was $7.1 \mathrm{mg} / \mathrm{L}$ $(0.12 \mathrm{mM})$. The absence of measurable sulfate is likely due to the presence of barium (594 mg/L; $4.33 \mathrm{mM})$, leading to the precipitation of barite $\left(\mathrm{BaSO}_{4}\right)$. The high salinity of this formation water is reflected by sodium and chloride concentrations being $45,404 \mathrm{mg} / \mathrm{L}$ $(1.97 \mathrm{M})$ and $83,211 \mathrm{mg} / \mathrm{L}(2.35 \mathrm{M})$, respectively. These values are similar to those of other highly saline oil reservoirs reported in other studies [34-37]. Reservoirs in the Antrim shale formation (United States) have concentrations of 1080 to $40,365 \mathrm{mg} / \mathrm{L}$ sodium (45.04 mM to $1.68 \mathrm{M}$ ) and 4284 to $124,000 \mathrm{mg} / \mathrm{L}$ chloride (136.08 $\mathrm{mM}$ to $3.50 \mathrm{M}$ ) [38]. Barium, calcium, magnesium and strontium were also reported at higher concentrations than other metals in the samples at $594 \mathrm{mg} / \mathrm{L}(4.33 \mathrm{mM}), 5434 \mathrm{mg} / \mathrm{L}(135.60 \mathrm{mM}), 2005 \mathrm{mg} / \mathrm{L}(82.51 \mathrm{mM})$ and $633 \mathrm{mg} / \mathrm{L}(7.22 \mathrm{mM})$, respectively. These high metal concentrations remain within the range reported in other oil reservoir formation waters [39-41].

\subsection{Microbial Community Composition}

Microbial diversity was first assessed by $16 \mathrm{~S}$ rRNA gene sequencing. The community composition revealed by amplicon sequencing of the produced water and enrichment cultures is summarized in Figure 1. Surprisingly, despite amplicon libraries having over 10,000 reads, only 10 OTUs from 7 genera were identified across both the original formation water and the two enrichment cultures (based on a cut-off of $1 \%$ relative abundance; Figure 1). This unusually low diversity illustrates the extreme conditions of this highsalinity environment, and is believed to be a good reflection of the in situ diversity owing to the unlikelihood of contamination taking hold in a high salinity sample as well as the potential for DNA preservation in high salt solutions [42]. All three samples were also investigated by metagenomic sequencing that targeted genome assemblies to better understand the physiology of organisms living in the reservoir. A co-assembly strategy that also incorporated metagenomes of the two enrichments revealed genomes from organisms that were presumably present in low abundance in the original formation water, in addition to genomes corresponding to the taxa that were likely dominant in situ.

\subsection{Metagenome Assembled Genomes and Key Metabolisms from a High Salinity Offshore Oil Reservoir}

Nine metagenome-assembled genomes (MAGs), shown in Table 1, were obtained from co-assembly of the three samples. As observed in the 16S rRNA gene dataset (Figure 1), most MAGs belong to genera commonly detected in subsurface petroleum reservoir systems, including Geotoga, Halanaerobium, Flexistipes, Marinobacter, Methanohalophilus and Arhodomonas [5,29,43,44]. In addition, MAGs for two novel organisms, classified at the genus level as QPJE01 (within the family Halanaerobiaceae) and at the family level as BM520 (within the order Bacteroidales), were recovered. 


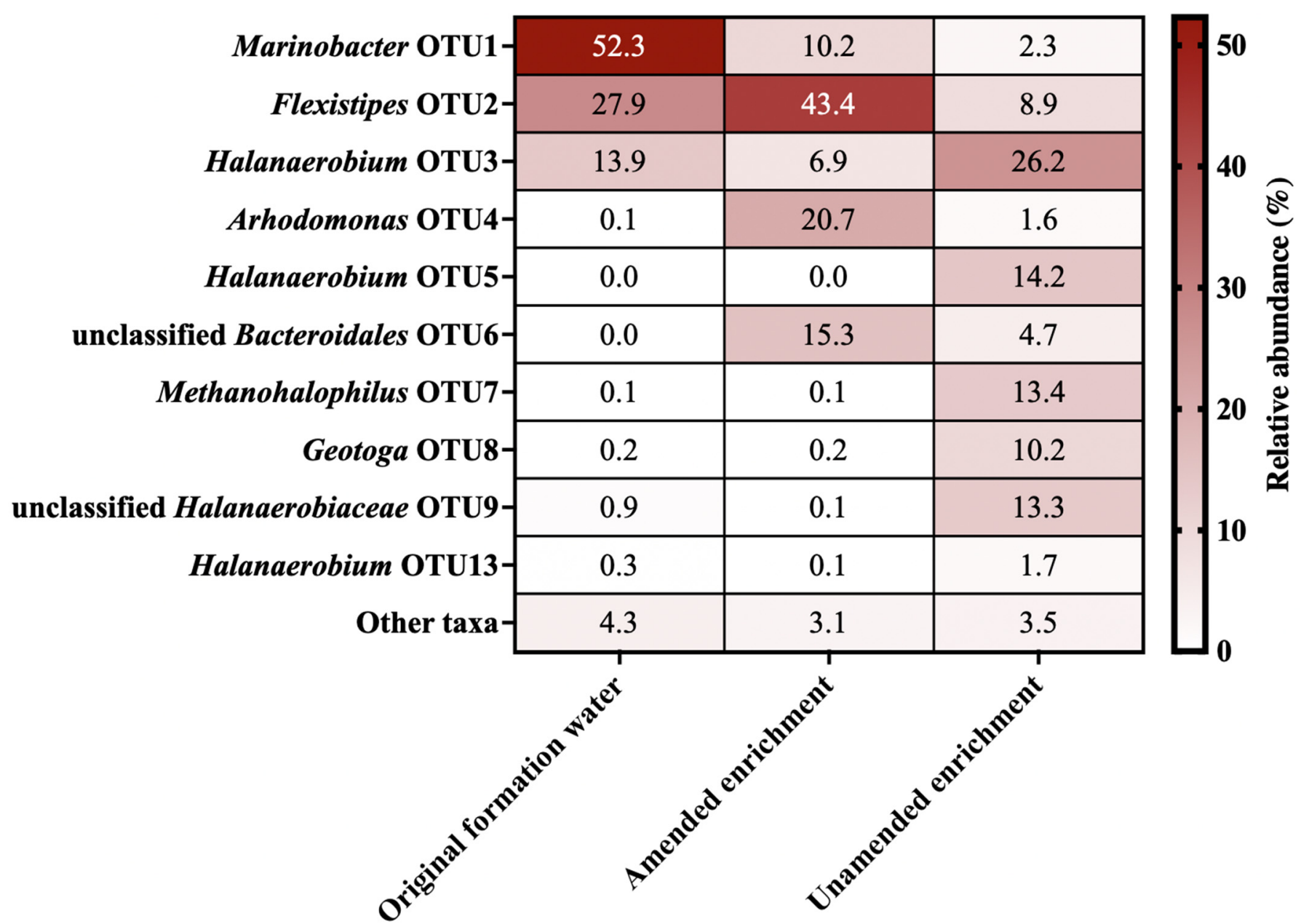

Figure 1. Microbial community composition in the original formation water and in amended and unamended enrichments incubated for 247 days. OTUs are defined by $97 \%$ sequence identity of $16 \mathrm{~S}$ rRNA gene sequences. Community compositions are based on comparing 10,000 sequence reads per sample. OTUs with relative sequence abundances below $1 \%$ are grouped together as "Other taxa". OTUs 6 and 9 have taxonomic assignments lower than $80 \%$ and could not be classified at the genus level.

Reconstructed genome completeness for the novel lineages QJPE01 and BM520 was $100 \%$ and $98.59 \%$, respectively, with very low redundancy (Table 1). Estimated genome completeness is based on the recovery of marker genes present within the genome, and redundancy (also known as contamination) is based on the number of copies of certain marker genes as determined by both CheckM and Anvi'o [25,45]. As such, for other MAGs with lower completeness such as Geotoga (MAGs 1 and 9), Methanohalophilus (MAG 3), and Halanaerobium (MAG 6) it is not possible to determine whether the absence of certain metabolic features (see below) is due to the true genotype or is rather due to the lower genome completeness (Table 1). Metabolic pathways found within the MAGs are summarized in Table 2 and detailed in Supplementary Material File S2. While these organisms and genes are derived from the high salinity oil reservoir, these metagenomic findings and analyses do not necessarily reflect the structure of the in situ microbial community within the oil formation. The discussion below explores the functional capabilities of these members of the microbiome, which may be present in high relative abundance in situ or are less abundant but able to grow quickly given appropriate conditions, such as those presented in the enrichment cultures. 
Table 1. Metagenome parameters and taxonomic assignments of 9 MAGs from oil reservoir formation water.

\begin{tabular}{|c|c|c|c|c|c|c|c|c|c|c|}
\hline & Bin Name & MAG 1 & MAG 2 & MAG 3 & MAG 4 & MAG 5 & MAG 6 & MAG 7 & MAG 8 & MAG 9 \\
\hline \multirow{6}{*}{$\begin{array}{l}\text { Sequence } \\
\text { statistics }\end{array}$} & Total length (bp) & $1,452,146$ & $3,984,249$ & $1,369,581$ & $2,973,006$ & $2,998,729$ & $2,088,230$ & $2,003,357$ & $3,539,121$ & $1,490,822$ \\
\hline & Number of contigs & 312 & 327 & 217 & 100 & 96 & 227 & 185 & 151 & 293 \\
\hline & N50 & 4863 & 19,895 & 7432 & 52,585 & 79,451 & 12,403 & 15,484 & 33,161 & 5366 \\
\hline & GC content (\%) & 29.33 & 69.87 & 42.84 & 58.14 & 41.21 & 33.17 & 33.80 & 43.35 & 30.18 \\
\hline & Completion (\%) & 76.06 & 98.59 & 76.32 & 92.96 & 97.18 & 59.15 & 100.00 & 98.59 & 47.89 \\
\hline & Redundancy (\%) & 2.82 & 7.04 & 6.58 & 2.82 & 2.82 & 5.63 & 1.41 & 1.41 & 2.82 \\
\hline \multirow{6}{*}{$\begin{array}{l}\text { Taxonomic } \\
\text { assignation }\end{array}$} & Domain & Bacteria & Bacteria & Archaea & Bacteria & Bacteria & Bacteria & Bacteria & Bacteria & Bacteria \\
\hline & Class & Thermotogae & Gammaproteobacteria & Methanomicrobia & Gammaproteobacteria & Deferribacteres & Clostridia & Clostridia & Bacteroidia & Thermotogae \\
\hline & Order & Petrotogales & Chromatiales & Methanosarcinales & Alteromonadales & Deferribacterales & Halanaerobiales & Halanaerobiales & Bacteroidales & Petrotogales \\
\hline & Family & Petrotogaceae & Ectothiodospiraceae & Methanosarcinaceae & Alteromonadaceae & Defferibacteraceae & Halanaerobiaceae & Halanaerobiaceae & BM520 & Petrotogaceae \\
\hline & Genus & Geotoga & Arhodomonas & Methanohalophilus & Marinobacter & Flexistipes & Halanaerobium & QPJE01 & - & Geotoga \\
\hline & Species & G. petraea & A. aquaeolei & M. euhalobius & M. persicus & F. sinusarabici & H. congolense & sp003337245 & - & G. petreae \\
\hline
\end{tabular}


Table 2. Summary of metabolic potential for reconstructed MAGs derived from oil reservoir formation water.

\begin{tabular}{|c|c|c|c|c|c|c|c|c|c|c|c|}
\hline & & Bin Name & MAG 1 & MAG 2 & MAG 3 & MAG 4 & MAG 5 & MAG 6 & MAG 7 & MAG 8 & MAG 9 \\
\hline & & Taxonomy & $\begin{array}{l}\text { Geotoga } \\
\text { petraea }\end{array}$ & $\begin{array}{c}\text { Arhodomonas } \\
\text { aquaeolei }\end{array}$ & $\begin{array}{l}\text { Methanohalophilus } \\
\text { euhalobius }\end{array}$ & $\begin{array}{c}\text { Marinobacter } \\
\text { persicus }\end{array}$ & $\begin{array}{c}\text { Flexistipes } \\
\text { sinusarabici }\end{array}$ & $\begin{array}{c}\text { Halanaerobium } \\
\text { congolense }\end{array}$ & QPJE01 & BM520 & $\begin{array}{l}\text { Geotoga } \\
\text { petreae }\end{array}$ \\
\hline & & Completion (\%) & 76.06 & 98.59 & 76.32 & 92.96 & 97.18 & 59.15 & 100.00 & 98.59 & 47.89 \\
\hline Metabolism & Reaction & & & & & & & & & & \\
\hline \multirow{5}{*}{ Fermentation } & $\begin{array}{l}\text { Acetate } \\
\text { production } \\
\text { (Wood- } \\
\text { Ljungdahl } \\
\text { pathway) }\end{array}$ & & & & & & & & & & \\
\hline & $\begin{array}{l}\text { Succinate } \\
\text { production } \\
\text { (glyoxylate } \\
\text { cycle) }\end{array}$ & & & & & & & & & & \\
\hline & $\begin{array}{l}\text { Hydrogen } \\
\text { production }\end{array}$ & & & & & & & & & & \\
\hline & $\begin{array}{l}\text { Ethanol } \\
\text { production }\end{array}$ & & & & & & & & & & \\
\hline & $\begin{array}{c}\text { Peptide } \\
\text { degradation }\end{array}$ & & & & & & & & & & \\
\hline $\begin{array}{c}\text { Hydrocarbon } \\
\text { degradation }\end{array}$ & $\begin{array}{l}\text { Benzene/toluene } \\
\text { degradation }\end{array}$ & & & & & & & & & & \\
\hline Methanogenesis & Methylotrophy & & & & & & & & & & \\
\hline \multirow{2}{*}{$\begin{array}{l}\text { Sulfur } \\
\text { metabolism }\end{array}$} & $\begin{array}{c}\text { thiosulfate } \\
\text { oxidation }\end{array}$ & & & & & & & & & & \\
\hline & $\begin{array}{l}\text { thiosulfate } \\
\text { reduction }\end{array}$ & & & & & & & & & & \\
\hline \multirow[t]{2}{*}{$\begin{array}{l}\text { Nitrogen } \\
\text { metabolism }\end{array}$} & $\begin{array}{c}\text { Dissimilatory } \\
\text { nitrate } \\
\text { reduction } \\
\end{array}$ & & & & & & & & & & \\
\hline & Denitrification & & & & & & & & & & \\
\hline
\end{tabular}


Table 2. Cont

\begin{tabular}{|c|c|c|c|c|c|c|c|c|c|c|c|}
\hline & & Bin Name & MAG 1 & MAG 2 & MAG 3 & MAG 4 & MAG 5 & MAG 6 & MAG 7 & MAG 8 & MAG 9 \\
\hline & & Taxonomy & $\begin{array}{l}\text { Geotoga } \\
\text { petraea }\end{array}$ & $\begin{array}{c}\text { Arhodomonas } \\
\text { aquaeolei }\end{array}$ & $\begin{array}{l}\text { Methanohalophilus } \\
\text { euhalobius }\end{array}$ & $\begin{array}{c}\text { Marinobacter } \\
\text { persicus }\end{array}$ & $\begin{array}{c}\text { Flexistipes } \\
\text { sinusarabici }\end{array}$ & $\begin{array}{c}\text { Halanaerobium } \\
\text { congolense }\end{array}$ & QPJE01 & BM520 & $\begin{array}{l}\text { Geotoga } \\
\text { petreae }\end{array}$ \\
\hline & & Completion (\%) & 76.06 & 98.59 & 76.32 & 92.96 & 97.18 & 59.15 & 100.00 & 98.59 & 47.89 \\
\hline Metabolism & Reaction & & & & & & & & & & \\
\hline \multirow{15}{*}{$\begin{array}{l}\text { Response to } \\
\text { environment }\end{array}$} & Salt-in & & & & & & & & & & \\
\hline & Salt-out & & & & & & & & & & \\
\hline & $\begin{array}{l}\text { Radiation } \\
\text { resistance }\end{array}$ & & & & & & & & & & \\
\hline & $\begin{array}{c}\mathrm{Mg} / \mathrm{Ca} \\
\text { acquisition }\end{array}$ & & & & & & & & & & \\
\hline & $\begin{array}{c}\text { Arsenate } \\
\text { reduction }\end{array}$ & & & & & & & & & & \\
\hline & Endosporulation & & & & & & & & & & \\
\hline & $\begin{array}{l}\text { Quorum } \\
\text { sensing }\end{array}$ & & & & & & & & & & \\
\hline & Biofilm & & & & & & & & & & \\
\hline & & \multicolumn{10}{|l|}{ Metabolic potential: } \\
\hline & & \multicolumn{10}{|l|}{ Present } \\
\hline & & \multicolumn{10}{|l|}{ Absent } \\
\hline & & \multicolumn{10}{|l|}{$100 \%$} \\
\hline & & \multicolumn{10}{|l|}{$50-99 \%$} \\
\hline & & \multicolumn{10}{|l|}{$1-49 \%$} \\
\hline & & $0 \%$ & & & & & & & & & \\
\hline
\end{tabular}


Succinate production potential was detected within the Arhodomonas, Marinobacter, Halanaerobium and Geotoga MAGs (Table 2). Based on the presence of acetate (7.1 mg/L; $0.12 \mathrm{mM}$ ) and absence of common electron acceptors in the formation water (sulfate, nitrate, carbonate; see Supplementary Material File S1), it is likely that organisms found within this environment rely mainly on fermentation. Potential for hydrogen metabolism was observed in Flexistipes (MAG 5) and Geotoga (MAG 9), which contained [NiFe]-hydrogenase genes. Geotoga (MAG 9) also contains hydA, which is essential for hydrogen production in other organisms such as Clostridium [46]. The final step for ethanol production is catalyzed by alcohol dehydrogenases that reduce organic compounds to ethanol, re-oxidizing $\mathrm{NADH}$ to NAD+ [47]. These enzymes are encoded within most of the MAGs including Geotoga (MAGs 1 and 9), Arhodomonas (MAG 2), Marinobacter (MAG 4) and Halanaerobiaceae (MAGs 6 and 7). Numerous peptidases were identified in all MAGs except the archaeal Methanohalophilus (MAG 3). Arhodomonas (MAG 2), Marinobacter (MAG 4), Flexistipes (MAG 5), QPJE01 (MAG 7) and Geotoga (MAG 9) genomes show potential for amino acid fermentation involving aminopeptidase and aminotransferase enzymes [29].

Both Halanaerobiaceae genomes (MAG 6 and 7) showed potential for solely fermentative metabolism including succinate production (MAG 6), ethanol production (both MAGs) and peptidase activity (MAG 7). Whereas Halanaerobium congolense MAG 6 is only a partially complete genome (59\%), the absence of any other metabolic pathways within the reconstructed genome of QJPE01 (MAG 7) with 100\% completeness suggests that this novel lineage is an acetoclastic, ethanol degrading organism that relies on fermentation. The type strain H. congolense that is closely related to MAG 6 is a fermenter that produces acetate, hydrogen and carbon dioxide [48].

\subsubsection{Carbon Metabolism}

Fermentation

Several MAGs contained genes indicative of fermentative metabolism. Identified pathways include acetogenesis, succinate production (glyoxylate cycle), hydrogen production, ethanol production and peptide degradation [49]. All nine MAGs from the formation water contained genes for the Wood-Ljungdahl pathway (acetate production).

\section{Hydrocarbon Biodegradation}

Arhodomonas aquaeolei (MAG 2) contains genes associated with the aerobic metabolism of benzene and toluene. Benzene can be converted to phenol and further converted to catechol by the phenol/toluene 2-monooxygenase ( clusters) [50]. The same gene clusters can also convert toluene to 2-hydroxytoluene and then to 3-methylcatechol [50]. Both catechol and methylcathecol intermediates can be further metabolized to formate or pyruvate and integrated into the glyoxylate or glycolysis pathways, respectively [29]. In MAG 2, the pathway for catechol compound conversion to pyruvate is incomplete despite this genome's $>98 \%$ estimated completeness, suggesting this organism uses the glyoxylate pathway ( $80 \%$ of these genes were detected in MAG 2). Arhodomonas aquaeolei was reported previously to be able to convert phenol to catechol [51-53], but these studies did not highlight benzene or toluene degradation for this species.

\section{Methanogenesis}

Methanohalophilus euhalobius (MAG 3) was the only methanogen found within the formation water sample. This organism is commonly detected in highly saline oil reservoirs and is known as an obligate methylotrophic methanogen [54]. Methanohalophilus spp. are predominant halophilic methylotrophic methanogens within the order Methanosarcinales, and use the classical methylotrophic pathway that converts methylated compounds to methane and carbon dioxide; MAG 3 has all genes associated with this pathway [54]. 


\subsubsection{Sulfur Metabolism}

\section{SOX System}

The SOX system in bacteria allows for thiosulfate and elemental sulfur oxidation to sulfate and is a major part of the sulfur cycle [55]. Some but not all genes that are part of the thiosulfate oxidation pathway were found in Arhodomonas (Figure 2). MAG 2 also includes soxC and soxD genes, which are involved in the conversion of elemental sulfur to sulfate [55]. An incomplete SOX pathway in a nearly complete genome $(98.59 \%$ completeness) suggests that this Arhodomonas can potentially oxidize elemental sulfur, which has been reported to accumulate in some sour reservoirs [56]. Oxidation of sulfur to sulfate could potentially generate an electron acceptor for the production of sulfide through dissimilatory sulfate reduction [57].

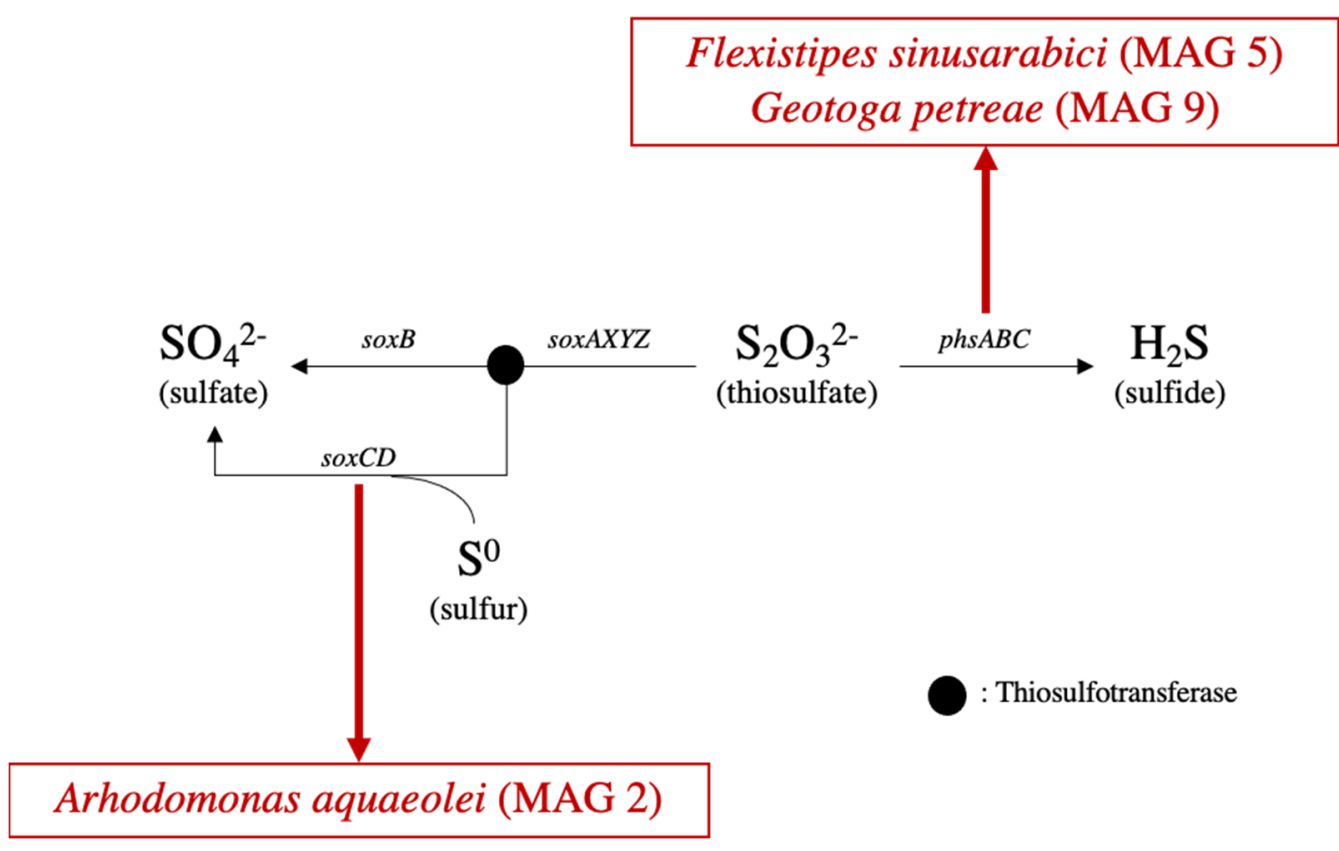

Figure 2. Genes present within MAGs for thiosulfate oxidation (SOX system-left branch) and thiosulfate reduction (right branch).

Thiosulfate Reduction

Reduction of thiosulfate to sulfide can be mediated by phs $A B C$ (Figure 2), which were found within the genomes of Flexistipes sinusarabici (MAG 5) and Geotoga petraea (MAG 9). Sulfide production by members of both of these genera has been reported previously $[43,58]$. Halanaerobium congolense is also a thiosulfate and elemental sulfur respiring organism [48]; however, associated genes were not detected in closely related MAG 6, possibly due to its low genome completeness (59\%; Table 1 ).

\subsubsection{Nitrogen Metabolism}

Dissimilatory Nitrate Reduction to Ammonia (DNRA)

The Nar complex consists of three different subunits (GHI) involved in the reduction of nitrate to nitrite, as shown in Figure 3 [59]. Arhodomonas aquaeolei (MAG 2) is known to reduce nitrate but not nitrite [44], consistent with narGHI genes being identified within the genome of MAG 2 (Figure 3). This Nar gene complex was also found in the genome of Flexistipes sinusarabici (MAG 5), contrary to another study of a different member of this species [58]. The same complex was also found within Geotoga (MAG 9), consistent with Geotoga spp. being reported to grow under nitrate-reducing conditions [60]. In this reservoir, Geotoga petrae (MAG 9) is shown to contain these DNRA genes. In addition to the Nar complex, napA (nitrate reductase cytochrome; Figure 3) was identified in Arhodomonas (MAG 2) and Flexistipes (MAG 5) genomes, as demonstrated previously in 
Flexistipes sinusarabici [58]. Arhodomonas aquaeolei (MAG 2) and Geotoga petraea (MAG 9) contain the nirBD and nrfAH genes involved in the reduction of nitrite to ammonia, the second step in DNRA (Figure 3).

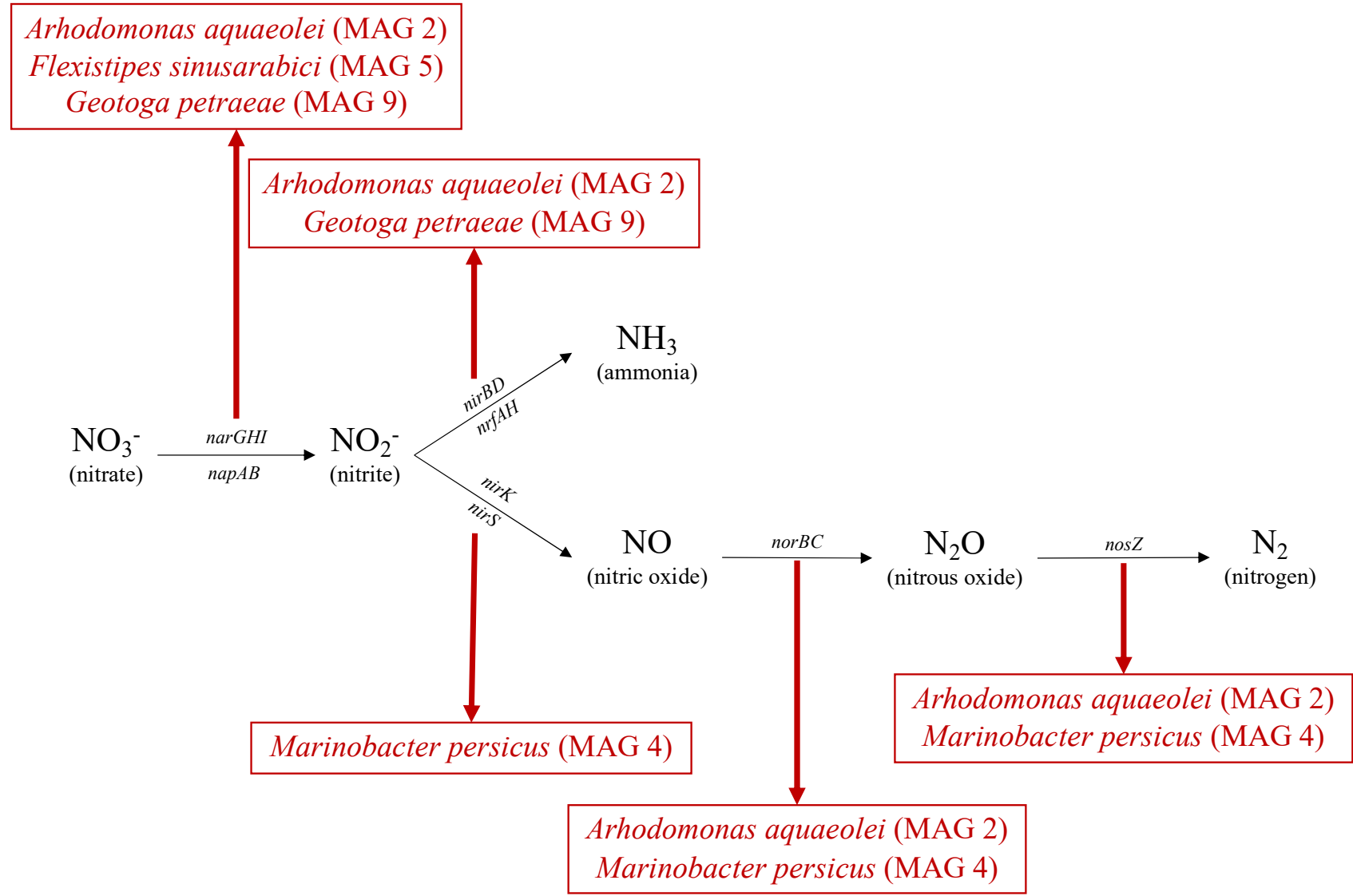

Figure 3. Genes present within MAGs for dissimilatory nitrate reduction (top branch) and denitrification (bottom branch).

\section{Denitrification}

For complete denitrification, narGHI and/or napAB (common to DNRA and denitrification), nirK or nirS, nor $B C$ and nosZ are typically required to reduce nitrate to dinitrogen gas, as shown in Figure 3. The Arhodomonas genome (MAG 2), in addition to containing genes for dissimilatory nitrate reduction (encoding narGHI), also encodes nitric- and nitrous oxide reductases (norBC and nosZ, respectively) that catalyze the final two steps in the denitrification pathway (Figure 3). Similar findings were observed in the Marinobacter persicus genome (MAG 4), where nirS, norBC and nosZ are present, but narGHI is missing. Given the high completeness of MAG $4(92.96 \%)$, these findings suggest that nitrate may not be metabolized by this Marinobacter, which can still potentially reduce nitrite to nitrogen gas. Other members of the Marinobacter genus have been reported to be able to catalyze complete denitrification [61].

\subsubsection{Nitrogen and Sulfur Metabolism in the Context of Souring and Souring Control}

Addition of nitrate to control sulfide-producing organisms has the potential to mitigate reservoir souring $[11,12,60,62,63]$. In this context, nitrate-reducing microorganisms (NRM) are able to influence sulfide production by two main mechanisms: biocompetitive exclusion of sulfide-producing organisms via NRM oxidizing electron donors that would otherwise support sulfate reduction, and nitrate reduction directly coupled to sulfide oxidation by chemolithotrophic NRM [62]. Whether these mechanisms are operative under highly saline conditions, such as those in this reservoir, has not received a lot of investigation. An 
et al. [11] showed that nitrite accumulation successfully controlled souring in enrichment cultures of samples from the Bakken shale formation, revealing the potential for nitrite inhibition of SRB at higher salinities. In the oil reservoir studied here, four MAGs exhibit the potential for nitrate metabolism, either via DNRA in Flexistipes (MAG 5) and Geotoga (MAG 9), or via denitrification in Arhodomonas (MAG 2) and Marinobacter (MAG 4). These MAGs likely represent organotrophic NRM, as no sulfide oxidizing genes were detected (Section 3.3.2). This suggests biocompetitive exclusion as a more likely mechanism for nitrate-based control of sulfide-producing organisms like Flexistipes (MAG 5) and Geotoga (MAG 9) if this reservoir were to sour. Overall, the in situ microbial community of this high salinity reservoir shows the metabolic potential for souring control via nitrate injection if this measure is needed during future operations.

\subsection{Novel Lineages}

\subsubsection{Reconstructed Genome of BM520}

Members of the order Bacteroidales are commonly found in oil reservoirs [64], including those that have experienced biodegradation. This has led to speculation about their potential involvement in this process as fermentative partners for methanogens [65-67]. Bacteroidales have been found in onshore and offshore oil reservoirs in Canada, China, the Danish North Sea, Gabon, the Norwegian Sea and the United States [64,68]. As shown in Figure 4A, the high bootstrap support for separating the BM520 family from other Bacteroidales adds confidence to its classification as a separate group. Despite the high completeness of the BM520 genome (98.59\%) and its genome size (3.5 kB), very few recognized metabolic genes were detected. Some Bacteroidales can produce acetate when degrading organic compounds in syntrophy with hydrogen producers, in agreement with the BM520 genome discovered here (Table 2) [67,69]. MAG 8 also includes genes associated with butyrate production but (butyrate kinase) and $p t b$ (phosphate butyryltransferase) (data not shown), similar to observations for Bacteroidales in the human gut [70]. Discoveries of organisms and genomes such as BM520 will help to further elucidate the biogeochemical role of Bacteroidales in oil reservoirs.

\subsubsection{Reconstructed Genome of QPJE01}

Members of the genus QPJE01 are distantly related to Halanaerobium spp., which are prevalent in oil fields, especially those produced by hydraulic fracturing (Figure 4B) [71,72]. Organisms within the family Halanaerobiaceae are often predominant in high salinity reservoirs with temperatures below $50^{\circ} \mathrm{C}$ [72]. Bootstrap values throughout the Halanaerobiaceae phylogeny shown in Figure 4B support QPJE01 representing a novel genus within this family. The genome completeness $(100 \%)$ and contamination $(1.41 \%)$ for MAG 7 allow its metabolic potential to be inferred with greater confidence. Members of the related genus Halanaerobium are considered thiosulfate-reducing sulfidogens that are also capable of fermentative metabolism [71,73]. Genes associated with fermentation are abundant in QPJE01 MAG 7 (see Section 3.3.1); however, thiosulfate reduction and sulfide production genes were not found in this genome (Section 3.3.2; Table 2). 


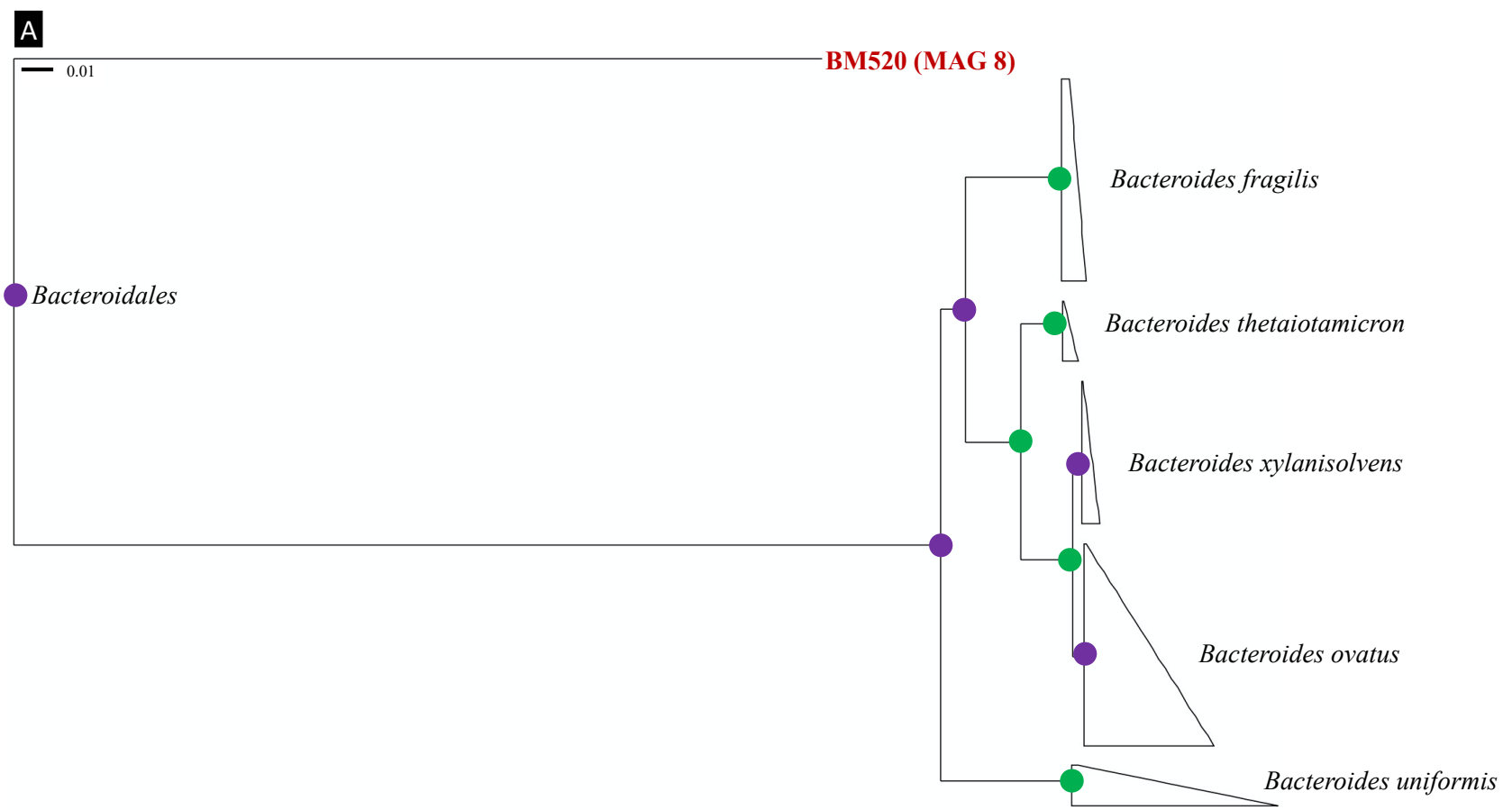

B
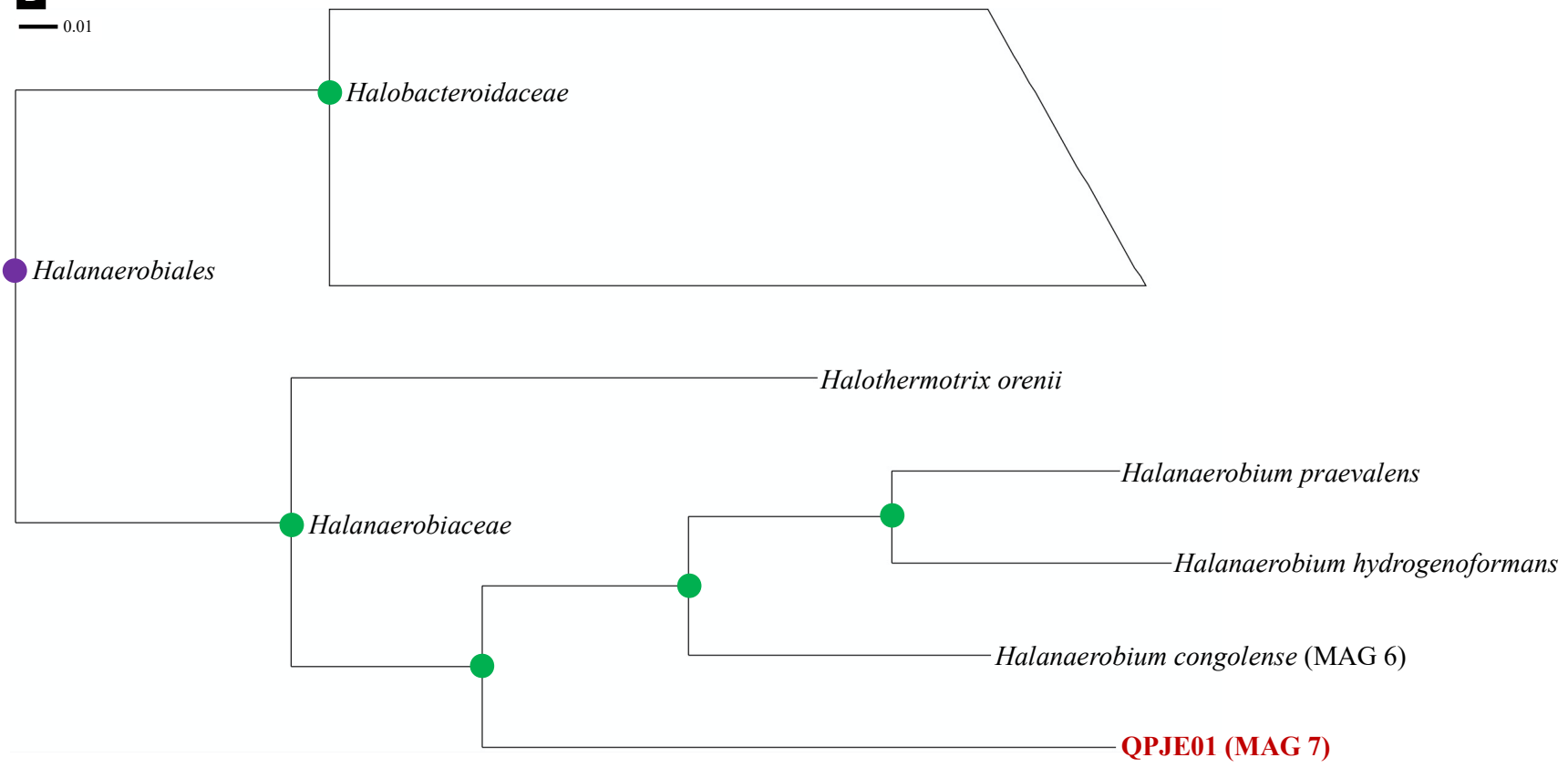

Figure 4. Phylogeny of novel lineages detected in oil reservoir formation water affiliated with (A) the order Bacteroidales, and (B) the family Halanaerobiaceae. The tree is based on CheckM phylogeny and only shows selected lineages from the orders Bacteroidales and Halanaerobiales. Green circles represent bootstrap values of 1.000 and purple circles represent bootstrap values between 0.900 and 0.999 . Novel organisms are highlighted in bold red. The scale bars indicate $1 \%$ sequence divergence.

\subsection{Adaptation to Extreme Environmental Conditions}

\subsubsection{Salt Adaptation}

Microorganisms that are able to function in highly saline environments do so by implementing either the "salt-in" or "salt-out" strategy [74]. The salt-in strategy involves the exclusion of sodium ions and accumulation of potassium ions in the cell to balance osmotic pressure with the environment [75]. Certain halophilic and fermentative organisms 
accumulate sodium ions rather than potassium ions for this purpose [76]. The salt-out strategy depends on the accumulation of compatible solutes (organic molecules) that maintain osmotic pressure while removing intracellular salts $[29,75]$. Different organic molecules can be synthesized or taken up from the surrounding environment to counter the effect of salinity. These include glycine betaine, hydroectoine, polar amino acids (e.g., proline) or sugars (e.g., sorbitol, trehalose, maltose, mannitol) [29,75]. MAGs were examined for genomic evidence for these salt adaptation strategies.

Salt-In Strategy

Potassium uptake systems expressed by trkH and phaABCDEFG were detected in all bacterial genomes, but not in the archaeal genome of Methanohalophilus euhalobius (MAG 3; $76 \%$ completeness), which included only a single sodium uptake system (mnhABCDEFG). A different sodium uptake system (nhaC) was detected in Geotoga (MAG 9), Marinobacter (MAG 4), Halanaerobium (MAG 6) and QJPE01 (MAG 7) genomes.

\section{Salt-Out Strategy}

Ectoine synthesis genes (ectABCD) were found in the Arhodomonas (MAG 2) and Marinobacter (MAG 4) genomes. These two genomes also contain transporter genes for glycine betaine (bet $A B L$ ) and proline (proPQVWX), whereas opuABCD was found in Arhodomonas (MAG 2), and bet $A B C$ and opuABCD were found in Marinobacter (MAG 4). Ectoine/hydroxyectoine transporter genes (ehuABCD) were found in Flexistipes (MAG 5), Halanaerobium (MAG 6) and QJPE01 (MAG 7) genomes. The Flexistipes genome (MAG 5) also contains genes for a glutamine transport system, and glycine/sarcosine methyltransferase genes were found in the genome of Methanohalophilus (MAG 3). Trehalose synthesis genes (ots $A B$ ) were only found in the two Halanaerobiaceae genomes (MAG 6 and 7), and QJPE01 (MAG 7) was the only genome that contained srlABE genes involved in sorbitol transport. Interestingly, no evidence of these known salt adaptation mechanisms was observed in the Bacteroidales genome (BM520; MAG 8) despite its $98.59 \%$ completeness. This is perhaps consistent with the general lack of recognizable genes within this genome (see Section 3.4.1 above), suggesting that this novel organism is adapted to high-salt environments utilizing another type of mechanism. These results are summarized in Figure 5.

\subsubsection{Radiation Adaptation}

Oil reservoirs have been reported to have varying levels of naturally occurring radionuclides due to water-rock interactions [5]. In saline oil reservoirs with high chloride levels, the dissolution of radioactive materials may be accelerated [77]. Despite this, radiotolerant microorganisms in oil and gas reservoirs have received little attention relative to the focus placed on the non-reservoir obligate aerobe Deinococcus radiodurans and its bioremediation of radioactive waste [78]. The DetR DB database was created to track radioactive-resistant microorganisms and the genes that they encode that are important for radiation resistance. DetR DB reports 22 radiation-resistant organisms with three genes in common among all of them [30]. Nudix hydrolases are a protein family which hydrolyses nucleotides to regulate their level and eliminate potentially toxic derivatives [79]. SufB is important for increasing intracellular free iron, which helps repair radiation damage [80]. MutS is an endonuclease which is associated with DNA mismatch repairs [78]. These three genes were found in six out of the nine high salinity oil reservoir MAGs recovered in this study, i.e., Marinobacter (MAG 4), Flexistipes (MAG 5), Halanaerobium (MAG 6), QPJE01 (MAG 7), BM520 (MAG 8) and Geotoga (MAG 9). 


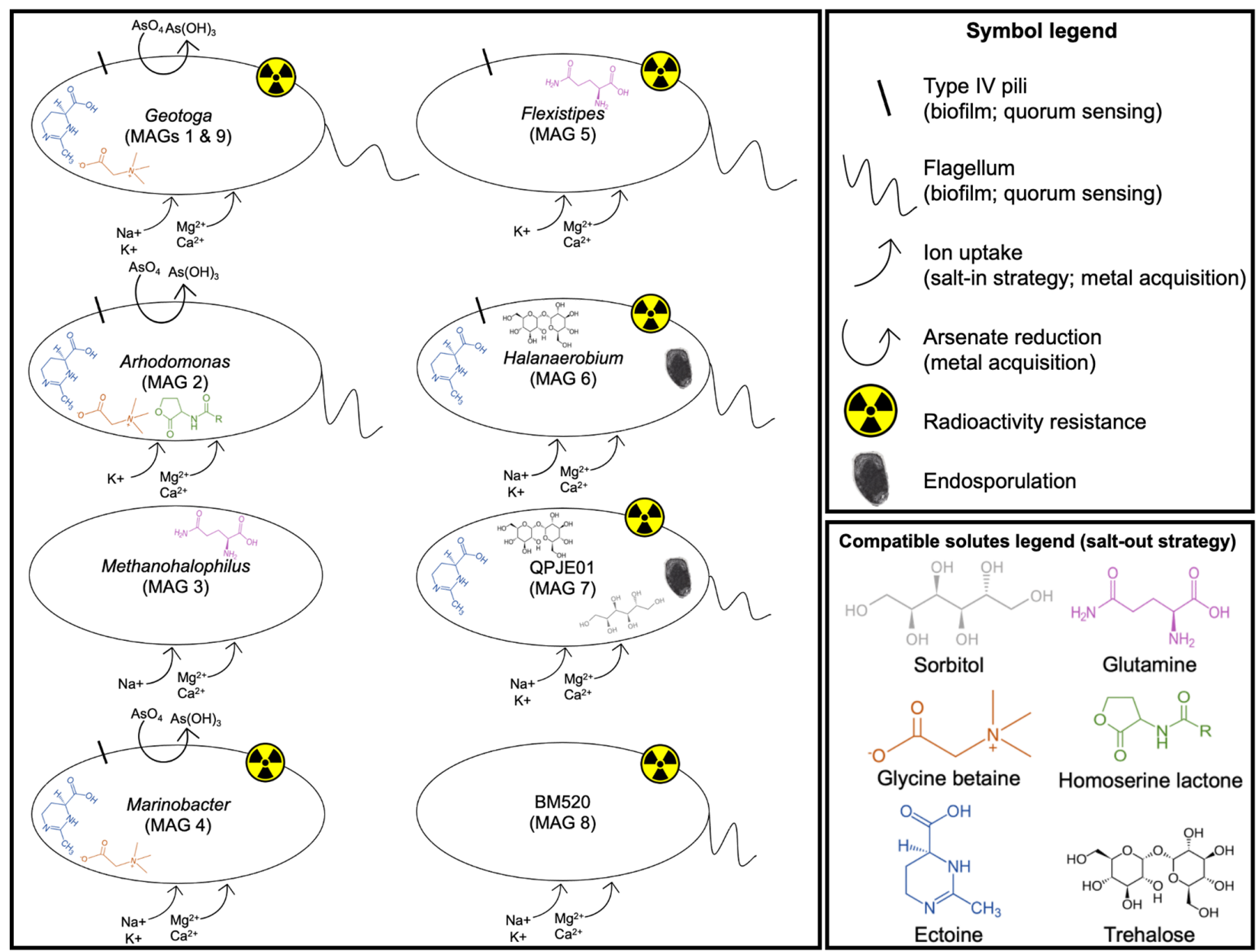

Figure 5. Potential environmental adaptations encoded in genomes from members of a Gulf of Mexico oil reservoir microbiome. Results from two Geotoga genomes (MAGs 1 and 9) are similar and are depicted together.

\subsubsection{Metal Acquisition}

Metal ions are necessary for organisms owing to their roles as cofactors for metabolic processes [81]. Barium and strontium have been considered as inert and non-essential to microbial life, so even though they were in higher concentrations in the sample, these metals were not considered in genomic investigations that rather focused on $\mathrm{Mg}^{2+}$ and $\mathrm{Ca}^{2+}$ and their known biological effects [82-84]. In addition to extremely high salinity in the oil reservoir, $5434 \mathrm{mg} / \mathrm{L}$ calcium $(135.60 \mathrm{mM})$ and $2005 \mathrm{mg} / \mathrm{L}$ magnesium $(82.51 \mathrm{mM})$ were detected in the formation water (Section 3.1).

All nine MAGs included genes for magnesium and calcium acquisition mechanisms. Magnesium has been reported to be toxic at around $500 \mathrm{mg} / \mathrm{L}(20.58 \mathrm{mM})$, while maximum intracellular calcium levels are usually kept around $4 \mathrm{mg} / \mathrm{L}(0.10 \mathrm{mM})$ [85]. All MAGs had at least one of the genes responsible for magnesium uptake processes ( $m g t E$ or cor $A$ ), and all had $y r b G$ for calcium uptake. Genes for the reduction of arsenate were detected in Geotoga, Arhodomonas and Marinobacter genomes (MAGs 1, 2, 4 and 9). The absence of respiratory arsenate oxidase or reductase $(a s o A / B)$ points to the potential for reduction of arsenate only to control its toxicity [86] and not for respiration in these organisms.

\subsubsection{Endosporulation}

Halanaerobium congolense has been studied in pure culture since 1997 [48]. The genus has been detected in many oil reservoir microbial communities, usually in association with highly salinity, and has received attention in recent years in the context of hydraulic frac- 
turing $[71,87,88]$. Although these organisms are persistent in oil reservoirs, only recently has it been proposed that the oil reservoir isolate Halanaerobium congolense has the ability to form endospores [31]. Two MAGs from the Halanaerobiaceae family (MAGs 6 and 7) were therefore assessed for the presence of genes encoding 136 endosporulation-specific proteins. For both genomes, all genes implicated in sporulation initiation (stage I), asymmetric septation (stage II), engulfment (stage III) and cortex formation (stage IV) were detected (Supplementary Material File S2). Three genes associated with the final stage of endosporulation (spore coat maturation; stage VI) are missing from both MAG 6 (Halanaerobium) and MAG 7 (QPJE01). Notably, mutants of Bacillus subtilis missing two of these genes (spsK and spsL) were still able to complete endosporulation [89]; these two genes as well as alr were also not found in the $H$. congolense strain reported recently as being capable of sporulation [31]. Taken together, these metagenomic results extend the potential for endosporulation more broadly among Halanaerobiaceae and within the oil reservoir microbiome.

\subsubsection{Quorum Sensing and Biofilm Formation}

One of the ways that microorganisms act synergistically in natural or engineered environments is through biofilm formation. Quorum sensing is the ability for cell-to-cell communication for gene regulation, and is an important capability governing the establishment of multi-cellular associations such as biofilms [90]. In the context of oil and gas operations, quorum sensing and biofilm formation have both been reported as prerequisites to microbially influenced corrosion [91].

The Arhodomonas (MAG 2) genome has an acyl homoserine lactone synthase gene (lasI), which is a key component in quorum sensing regulated coordination of gene expression in a cell-density dependent manner [92,93]. Additionally, Arhodomonas (MAG 2), Methanohalophilus (MAG 3), Marinobacter (MAG 4), Flexistipes (MAG 5) and Halanaerobium (MAG 6) genomes have phnAB clusters responsible for encoding the quinolone signal, originally characterized in Pseudomonas and responsible for controlling gene expression [94,95]. The Arhodomonas genome includes a complete chemosensory system (cAMP/vfr signaling system) that is known to induce type II and III secretion systems and type IV pili [96]. Genes for type IV pili were detected in Arhodomonas and Marinobacter (MAGs 2 and 4), indicating potential for close associations between cells and the exchange of DNA [97]. Geotoga (MAG 1), Arhodomonas (MAG 2), Flexistipes (MAG 5), Halanaerobium (MAG 6), QJPE01 (MAG 7) and BM520 (MAG 8) genomes all contained genes for flagellar biosynthesis and assembly, which are necessary for the transition state between motility and sessility during biofilm formation. Flagella have a mechanosensory role in surface sensing and are important for the initial stages of surface adhesion that eventually lead to biofilm formation [98].

\section{Conclusions}

Formation water from a high-salinity Gulf of Mexico oil reservoir revealed a lowdiversity microbial community to which a metagenomic sequencing strategy was applied to recover nine metagenome-assembled genomes with more than $50 \%$ completeness. Although the organisms investigated are most likely predominantly fermentative in this subsurface setting, potential for sulfide production, and hence reservoir souring, was detected in Arhodomonas and Geotoga. Genomic evaluation furthermore revealed the metabolic potential of this oil field microbiome to respond favorably to nitrate-based souring mitigation, with the potential for dissimilatory nitrate reduction and denitrification detected in Arhodomonas, Flexistipes, Geotoga and Marinobacter. Members of this microbiome, including two novel lineages BM520 and QJPE01, also have potential for quorum sensing and biofilm formation, and withstanding high salinity and the effects of potential radionuclide exposure in the subsurface. Endospore formation genes observed in Halanaerobiaceae highlight another mechanism for persistence of microbial populations in this poly-extreme environment.

Supplementary Materials: The following are available online at https:/ / www.mdpi.com/article/10 $.3390 /$ microorganisms $9112266 / \mathrm{s} 1$, The data in this study regarding water chemistry and metagenomic analyses are available in Supplementary Material File S1 and File S2, respectively. 
Author Contributions: D.R.E. secured offshore produced water samples, C.R.J.H., D.R.E., S.L. and J.R.d.R. designed the study, J.R.d.R. and S.L. performed incubations and DNA extractions, G.S. and J.R.d.R. performed genomic and computational analyses, and G.S. wrote the manuscript with input from J.R.d.R., C.R.J.H., D.R.E., J.M. and S.L. All authors have read and agreed to the published version of the manuscript.

Funding: This work was supported by grants from the UK Engineering and Physical Sciences Research Council (EP/J002259/1, EP/L001942/1), ExxonMobil Upstream Research Company (project EM09030) and the Natural Sciences and Engineering Research Council of Canada (NSERC) to C.R.J.H., and by scholarship funding to G.S. from NSERC (Alexander Graham Bell scholarship program), Natural Resources Canada and the Eyes High program (University of Calgary).

Institutional Review Board Statement: Not applicable.

Informed Consent Statement: Not applicable.

Data Availability Statement: $16 \mathrm{~S}$ rRNA gene sequencing data and metagenomics data have been deposited at NCBI under the accession number SUB10146380 (project ID PRJNA752507).

Acknowledgments: The authors would like to thank Srijak Bhatnagar, Rebecca Daly and Kelly Wrighton for bioinformatics support, Demelza Menendez Vega for laboratory assistance, and Jianwei Chen for valuable discussions.

Conflicts of Interest: The authors declare no conflict of interest.

\section{References}

1. Kohli, I.; Joshi, N.C.; Mohapatra, S.; Varma, A. Extremophile-An adaptive strategy for extreme conditions and applications. Curr. Genom. 2020, 21, 96-110. [CrossRef] [PubMed]

2. Merino, N.; Aronson, H.S.; Bojanova, D.P.; Feyhl-Buska, J.; Wong, M.L.; Zhang, S.; Giovannelli, D. Living at the extremes: Extremophiles and the limits of life in a planetary context. Front. Microbiol. 2019, 10, 1-25. [CrossRef]

3. Rampelotto, P.H. Extremophiles and extreme environments. Life 2013, 3, 482-485. [CrossRef]

4. Rothschild, L.J.; Mancinelli, R.L. Life in extreme environments. Nature 2001, 409, 1092-1101. [CrossRef]

5. Pannekens, M.; Kroll, L.; Müller, H.; Mbow, F.T.; Meckenstock, R.U. Oil reservoirs, an exceptional habitat for microorganisms. New Biotechnol. 2019, 49, 1-9. [CrossRef]

6. US EPA. Radioactive Waste Material from Oil and Gas Drilling. Available online: https://www.epa.gov/radtown/radioactivewaste-material-oil-and-gas-drilling (accessed on 20 May 2021).

7. Youssef, N.; Elshahed, M.S.; McInerney, M.J. Microbial processes in oil fields: Culprits, problems, and opportunities. Adv. Appl. Microbiol. 2009, 66, 141-251.

8. Sierra-Garcia, I.N.; de Oliveira, V.M. Microbial Hydrocarbon Degradation: Efforts to Understand Biodegradation in Petroleum Reservoirs; IntechOpen: London, UK, 2013.

9. Guan, J.; Zhang, B.-L.; Mbadinga, S.M.; Liu, J.-F.; Gu, J.-D.; Mu, B.-Z. Functional genes (Dsr) approach reveals similar sulphidogenic prokaryotes diversity but different structure in saline waters from corroding high temperature petroleum reservoirs. Appl. Microbiol. Biotechnol. 2014, 98, 1871-1882. [CrossRef] [PubMed]

10. Shi, X.; Oliveira, D.A.F.; Holsten, L.; Steinhauer, K.; de Rezende, J.R. Long-term biocide efficacy and its effect on a souring microbial community. Appl. Environ. Microbiol. 2021, 87, AEM0084221. [CrossRef]

11. An, B.A.; Shen, Y.; Voordouw, G. Control of sulfide production in high salinity Bakken shale oil reservoirs by halophilic bacteria reducing nitrate to nitrite. Front. Microbiol. 2017, 8, 1164. [CrossRef]

12. Veshareh, M.J.; Nick, H. Learnings from reservoir souring treatment by nitrate injection in the Halfdan oil field. In Proceedings of the 80th EAGE Conference and Exhibition 2018, Copenhagen, Denmark, 11-14 June 2018; pp. 1-5.

13. Payler, S.J.; Biddle, J.F.; Lollar, B.S.; Fox-Powell, M.G.; Edwards, T.; Ngwenya, B.T.; Paling, S.M.; Cockell, C.S. An ionic limit to life in the deep subsurface. Front. Microbiol. 2019, 10, 426-441. [CrossRef] [PubMed]

14. Quince, C.; Lanzen, A.; Davenport, R.J.; Turnbaugh, P.J. Removing noise from pyrosequenced amplicons. BMC Bioinform. 2011, 12, 38. [CrossRef]

15. De Rezende, J.R.; Oldenburg, T.B.P.; Korin, T.; Richardson, W.D.L.; Fustic, M.; Aitken, C.M.; Bowler, B.F.J.; Sherry, A.; Grigoryan, A.; Voordouw, G.; et al. Anaerobic microbial communities and their potential for bioenergy production in heavily biodegraded petroleum reservoirs. Environ. Microbiol. 2020, 22, 3049-3065. [CrossRef]

16. Schloss, P.D.; Westcott, S.L.; Ryabin, T.; Hall, J.R.; Hartmann, M.; Hollister, E.B.; Lesniewski, R.A.; Oakley, B.B.; Parks, D.H.; Robinson, C.J.; et al. Introducing mothur: Open-source, platform-independent, community-supported software for describing and comparing microbial communities. Appl. Environ. Microbiol. 2009, 75, 7537-7541. [CrossRef] [PubMed]

17. Schloss, P.D.; Gevers, D.; Westcott, S.L. Reducing the effects of PCR amplification and sequencing artifacts on 16s RRNA-based studies. PLoS ONE 2011, 6, e27310. [CrossRef] [PubMed] 
18. Wang, Q.; Garrity, G.M.; Tiedje, J.M.; Cole, J.R. Naive bayesian classifier for rapid assignment of rRNA sequences into the new bacterial taxonomy. Appl. Environ. Microbiol. 2007, 73, 5261-5267. [CrossRef] [PubMed]

19. JGI BBDuk Guide. Available online: https://jgi.doe.gov/data-and-tools/bbtools/bb-tools-user-guide/bbduk-guide/ (accessed on 31 October 2020).

20. FastQC-A Quality Control Tool for High Throughput Sequence Data. Available online: https://www.bioinformatics.babraham. ac.uk/projects/fastqc/ (accessed on 28 April 2021).

21. Kang, D.D.; Froula, J.; Egan, R.; Wang, Z. MetaBAT, an eficient tool for accurately reconstructing single genomes from complex microbial communities. PeerJ 2015, 3, 1165. [CrossRef]

22. Bowtie 2: Fast and Sensitive Read Alignment. Available online: http://bowtie-bio.sourceforge.net/bowtie2/index.shtml (accessed on 26 September 2020).

23. Genome Research Limited Samtools. Available online: http:/ / www.htslib.org/ (accessed on 28 April 2021).

24. An analysis and Visualization Platform For 'Omics Data. Available online: https://merenlab.org/software/anvio/ (accessed on 28 April 2021).

25. Parks, D.H.; Imelfort, M.; Skennerton, C.T.; Hugenholtz, P.; Tyson, G.W. CheckM: Assessing the quality of microbial genomes recovered from isolates, single cells, and metagenomes. Genome Res. 2015, 25, 1043-1055. [CrossRef]

26. Chaumeil, P.-A.; Mussig, A.J.; Hugenholtz, P.; Parks, D.H. GTDB-Tk: A toolkit to classify genomes with the genome taxonomy database. Bioinformatics 2020, 36, 1925-1927. [CrossRef]

27. Shaffer, M.; Borton, M.A.; McGivern, B.B.; Zayed, A.A.; La Rosa, S.L.; Solden, L.M.; Liu, P.; Narrowe, A.B.; Rodríguez-Ramos, J.; Bolduc, B.; et al. DRAM for distilling microbial metabolism to automate the curation of microbiome function. Nucleic Acids Res. 2020, 48, 8883-8900. [CrossRef]

28. Kanehisa, M.; Furumichi, M.; Sato, Y.; Ishiguro-Watanabe, M.; Tanabe, M. KEGG: Integrating viruses and cellular organisms. Nucleic Acids Res. 2021, 49, D545-D551. [CrossRef]

29. Daly, R.A.; Borton, M.A.; Wilkins, M.J.; Hoyt, D.W.; Kountz, D.J.; Wolfe, R.A.; Welch, S.A.; Marcus, D.N.; Trexler, R.V.; MacRae, J.D.; et al. Microbial metabolisms in a 2.5-km-deep ecosystem created by hydraulic fracturing in shales. Nat. Microbiol. 2016, 1, 16146. [CrossRef] [PubMed]

30. Ryabova, A.; Kozlova, O.; Kadirov, A.; Ananeva, A.; Gusev, O.; Shagimardanova, E. DetR DB: A database of ionizing radiation resistance determinants. Genes 2020, 11, 1477. [CrossRef]

31. Jones, A.A.; Pilloni, G.; Claypool, J.T.; Paiva, A.R.; Summers, Z.M. Evidence of sporulation capability of the ubiquitous oil reservoir microbe Halanaerobium congolense. Geomicrobiol. J. 2020, 38, 283-293. [CrossRef]

32. Protein BLAST: Search Protein Databases Using a Protein Query. Available online: https://blast.ncbi.nlm.nih.gov/Blast.cgi? PROGRAM=blastp\&PAGE_TYPE=BlastSearch\&LINK_LOC=blasthome (accessed on 28 April 2021).

33. Huson, D.H.; Rupp, R.; Berry, V.; Gambette, P.; Paul, C. Computing galled networks from real data. Bioinformatics 2009, 25, i85-i93. [CrossRef] [PubMed]

34. Head, I.M.; Gray, N.D.; Larter, S.R. Life in the slow lane; biogeochemistry of biodegraded petroleum containing reservoirs and implications for energy recovery and carbon management. Front. Microbiol. 2014, 5, 566. [CrossRef]

35. Grassia, G.S.; McLean, K.M.; Glénat, P.; Bauld, J.; Sheehy, A.J. A systematic survey for thermophilic fermentative bacteria and archaea in high temperature petroleum reservoirs. FEMS Microbiol. Ecol. 1996, 21, 47-58. [CrossRef]

36. Röling, W.F.M.; Head, I.M.; Larter, S.R. The microbiology of hydrocarbon degradation in subsurface petroleum reservoirs: Perspectives and prospects. Res. Microbiol. 2003, 154, 321-328. [CrossRef]

37. Gray, N.D.; Sherry, A.; Larter, S.R.; Erdmann, M.; Leyris, J.; Liengen, T.; Beeder, J.; Head, I.M. Biogenic methane production in formation waters from a large gas field in the North Sea. Extremophiles 2009, 13, 511-519. [CrossRef]

38. Waldron, P.J.; Petsch, S.T.; Martini, A.M.; Nüsslein, K. Salinity constraints on subsurface archaeal diversity and methanogenesis in sedimentary rock rich in organic matter. Appl. Environ. Microbiol. 2007, 73, 4171-4179. [CrossRef]

39. Binmerdhah, A.; Yassin, A. Solubility of common oil field scales of injection water and high-barium concentration and high-salinity formation water. J. Teknol. 2009, 50, 67-77.

40. Gamal, H.; Al-Afnan, S.; Elkatatny, S.; Bahgat, M. Barium sulfate scale removal at low-temperature. Geofluids 2021, 2021, 5527818. [CrossRef]

41. Mahmoud, M.; Elkatatny, S.; Abdelgawad, K.Z. Using high- and low-salinity seawater injection to maintain the oil reservoir pressure without damage. J. Pet. Explor. Prod. Technol. 2017, 7, 589-596. [CrossRef]

42. Borin, S.; Crotti, E.; Mapelli, F.; Tamagnini, I.; Corselli, C.; Daffonchio, D. DNA is preserved and maintains transforming potential after contact with brines of the deep anoxic hypersaline lakes of the Eastern Mediterranean sea. Saline Syst. 2008, 4, 10. [CrossRef] [PubMed]

43. Semenova, E.M.; Grouzdev, D.S.; Tourova, T.P.; Nazina, T.N. Physiology and genomic characteristics of Geotoga petraea, a bacterium isolated from a low-temperature petroleum reservoir (Russia). Microbiology 2019, 88, 662-670. [CrossRef]

44. Adkins, J.P.; Madigan, M.T.; Mandelco, L.; Woese, C.R.; Tanner, R.S. Arhodomonas aquaeolei gen. nov., sp. nov., an aerobic, halophilic bacterium isolated from a subterranean brine. Int. J. Syst. Bacteriol. 1993, 43, 514-520. [CrossRef]

45. Eren, A.M.; Kiefl, E.; Shaiber, A.; Veseli, I.; Miller, S.E.; Schechter, M.S.; Fink, I.; Pan, J.N.; Yousef, M.; Fogarty, E.C.; et al. Community-led, integrated, reproducible multi-omics with Anvi'o. Nat. Microbiol. 2021, 6, 3-6. [CrossRef] [PubMed] 
46. Kaji, M.; Taniguchi, Y.; Matsushita, O.; Katayama, S.; Miyata, S.; Morita, S.; Okabe, A. The HydA gene encoding the H(2)-evolving hydrogenase of Clostridium perfringens: Molecular characterization and expression of the Gene. FEMS Microbiol. Lett. 1999, 181, 329-336. [CrossRef]

47. Boock, J.T.; Freedman, A.J.E.; Tompsett, G.A.; Muse, S.K.; Allen, A.J.; Jackson, L.A.; Castro-Dominguez, B.; Timko, M.T.; Prather, K.L.J.; Thompson, J.R. Engineered microbial biofuel production and recovery under supercritical carbon dioxide. Nat. Commun. 2019, 10, 587. [CrossRef]

48. Ravot, G.; Magot, M.; Ollivier, B.; Patel, B.K.C.; Ageron, E.; Grimont, P.A.D.; Thomas, P.; Garcia, J.-L. Halanaerobium congolense sp. nov., an anaerobic, moderately halophilic, thiosulfate- and sulfur-reducing bacterium from an African oil field. FEMS Microbiol. Lett. 1997, 147, 81-88. [CrossRef]

49. Chakraborty, A.; Ruff, S.E.; Dong, X.; Ellefson, E.D.; Li, C.; Brooks, J.M.; McBee, J.; Bernard, B.B.; Hubert, C.R.J. Hydrocarbon seepage in the deep seabed links subsurface and seafloor biospheres. Proc. Natl. Acad. Sci. USA 2020, 117, 11029-11037. [CrossRef]

50. Lee, Y.; Lee, Y.; Jeon, C.O. Biodegradation of naphthalene, BTEX, and aliphatic hydrocarbons by Paraburkholderia aromaticivorans BN5 isolated from petroleum-contaminated soil. Sci. Rep. 2019, 9, 860. [CrossRef] [PubMed]

51. Bonfá, M.R.L.; Grossman, M.J.; Piubeli, F.; Mellado, E.; Durrant, L.R. Phenol degradation by halophilic bacteria isolated from hypersaline environments. Biodegradation 2013, 24, 699-709. [CrossRef] [PubMed]

52. Fathepure, B.Z. Recent studies in microbial degradation of petroleum hydrocarbons in hypersaline environments. Front. Microbiol. 2014, 5, 173. [CrossRef] [PubMed]

53. Das, N.; Chandran, P. Microbial degradation of petroleum hydrocarbon contaminants: An overview. Biotechnol. Res. Int. 2010, 2011, 941810. [CrossRef] [PubMed]

54. Guan, Y.; Nguyi, D.K.; Vinu, M.; Blom, J.; Alam, I.; Guillot, S.; Ferry, J.S.; Stingl, U. Comparative genomics of the genus Methanohalophilus, including a newly isolated strain from Kebrit deep in the Red Sea. Front. Microbiol. 2019, 10, 839. [CrossRef]

55. Grabarczyk, D.B.; Berks, B.C. Intermediates in the SOX sulfur oxidation pathway are bound to a sulfane conjugate of the carrier protein SoxYZ. PLoS ONE 2017, 12, e0173395. [CrossRef] [PubMed]

56. Tang, Y.; Voelker, J.; Keskin, C.; Xu, Z.; Hu, B.; Jia, C. A flow assurance study on elemental sulfur deposition in sour gas wells. In Proceedings of the SPE Annual Technical Conference and Exhibition, Denver, CO, USA, 30 October-2 November 2011.

57. Anantharaman, K.; Hausmann, B.; Jungbluth, S.P.; Kantor, R.S.; Lavy, A.; Warren, L.A.; Rappé, M.S.; Pester, M.; Loy, A.; Thomas, B.C.; et al. Expanded diversity of microbial groups that shape the dissimilatory sulfur cycle. ISME J. 2018, 12, 1715-1728. [CrossRef]

58. Slobodkin, A.; Slobodkina, G.; Allioux, M.; Alain, K.; Jebbar, M.; Shadrin, V.; Kublanov, I.; Toshchakov, S.; Bonch-Osmolovskaya, E. Genomic insights into the carbon and energy metabolism of a thermophilic deep-sea bacterium Deferribacter autotrophicus revealed new metabolic traits in the phylum Deferribacteres. Genes 2019, 10, 849. [CrossRef]

59. Coelho, C.; Romão, M.J. Structural and mechanistic insights on nitrate reductases. Protein Sci. 2015, 24, 1901-1911. [CrossRef]

60. Bødtker, G.; Lysnes, K.; Torsvik, T.; Bjørnestad, E.Ø.; Sunde, E. Microbial analysis of backflowed injection water from a nitratetreated North Sea oil reservoir. J. Ind. Microbiol. Biotechnol. 2009, 36, 439-450. [CrossRef]

61. Evans, M.V.; Panescu, J.; Hanson, A.J.; Welch, S.A.; Sheets, J.M.; Nastasi, N.; Daly, R.A.; Cole, D.R.; Darrah, T.H.; Wilkins, M.J.; et al. Members of Marinobacter and Arcobacter influence system biogeochemistry during early production of hydraulically fractured natural gas wells in the Appalachian Basin. Front. Microbiol. 2018, 9, 2646. [CrossRef]

62. Carlson, H.; Hubert, C. Mechanisms and monitoring of oil reservoir souring control by nitrate or perchlorate injection. In Microbial Communities Utilizing Hydrocarbons and Lipds: Members, Metagenomics and Ecophysiology; Springer International Publishing: New York, NY, USA, 2019; pp. 1-25.

63. Suri, N.; Voordouw, J.; Voordouw, G. The effectiveness of nitrate-mediated control of the oil field sulfur cycle depends on the toluene content of the oil. Front. Microbiol. 2017, 8, 956. [CrossRef]

64. Kim, D.D.; O’Farrell, C.; Toth, C.R.A.; Montoya, O.; Gieg, L.M.; Kwon, T.-H.; Yoon, S. Microbial community analyses of produced waters from high-temperature oil reservoirs reveal unexpected similarity between geographically distant oil reservoirs. Microb. Biotechnol. 2018, 11, 788-796. [CrossRef] [PubMed]

65. Wang, L.-Y.; Gao, C.-X.; Mbadinga, S.M.; Zhou, L.; Liu, J.-F.; Gu, J.-D.; Mu, B.-Z. Characterization of an alkane-degrading methanogenic enrichment culture from production water of an oil reservoir after 274 days of incubation. Int. Biodeterior. Biodegrad. 2011, 65, 444-450. [CrossRef]

66. Purwasena, I.A.; Sugai, Y.; Sasaki, K. The utilization of natural reservoir brine in an enrichment culture medium: An alternative approach for isolation of anaerobic bacteria from an oil reservoir. Pet. Sci. 2014, 32, 783-789. [CrossRef]

67. Shelton, J.L.; Akob, D.M.; McIntosh, J.C.; Fierer, N.; Spear, J.R.; Warwick, P.D.; McCray, J.E. Environmental drivers of differences in microbial community structure in crude oil reservoirs across a methanogenic gradient. Front. Microbiol. 2016, 7, 1535. [CrossRef] [PubMed]

68. Gales, G.; Tsesmetzis, N.; Neria, I.; Alazard, D.; Coulon, S.; Lomans, B.P.; Morin, D.; Ollivier, B.; Borgomano, J.; Joulian, C. Preservation of ancestral cretaceous microflora recovered from a hypersaline oil reservoir. Sci. Rep. 2016, 6, 22960. [CrossRef]

69. Qiu, Y.-L.; Hanada, S.; Ohashi, A.; Harada, H.; Kamagata, Y.; Sekiguchi, Y. Syntrophorhabdus aromaticivorans gen. nov., sp. nov., the first cultured anaerobe capable of degrading phenol to acetate in obligate syntrophic associations with a hydrogenotrophic methanogen. Appl. Environ. Microbiol. 2008, 74, 2051-2058. [CrossRef] [PubMed] 
70. Hwang, N.; Eom, T.; Gupta, S.K.; Jeong, S.-Y.; Jeong, D.-Y.; Kim, Y.S.; Lee, J.-H.; Sadowsky, M.J.; Unno, T. Genes and gut bacteria involved in luminal butyrate reduction caused by diet and loperamide. Genes 2017, 8, 350. [CrossRef]

71. Booker, A.E.; Borton, M.A.; Daly, R.A.; Welch, S.A.; Nicora, C.D.; Hoyt, D.W.; Wilson, T.; Purvine, S.O.; Wolfe, R.A.; Sharma, S.; et al. Sulfide generation by dominant Halanaerobium microorganisms in hydraulically fractured shales. MSphere 2017, 2, e00257-17. [CrossRef]

72. Mouser, P.J.; Borton, M.; Darrah, T.H.; Hartsock, A.; Wrighton, K.C. Hydraulic fracturing offers view of microbial life in the deep terrestrial subsurface. FEMS Microbiol. Ecol. 2016, 92, fiw166. [CrossRef]

73. Lipus, D.; Vikram, A.; Ross, D.; Bain, D.; Gulliver, D.; Hammack, R.; Bibby, K. Predominance and metabolic potential of Halanaerobium spp. in produced water from hydraulically fractured Marcellus shale wells. Appl. Environ. Microbiol. 2017, 83, e02659-16. [CrossRef] [PubMed]

74. Oren, A. Bioenergetic aspects of halophilism. Microbiol. Mol. Biol. Rev. 1999, 63, 334-348. [CrossRef] [PubMed]

75. Gunde-Cimerman, N.; Plemenitaš, A.; Oren, A. Strategies of adaptation of microorganisms of the three domains of life to high salt concentrations. FEMS Microbiol. Rev. 2018, 42, 353-375. [CrossRef] [PubMed]

76. Kivistö, A.; Larjo, A.; Ciranna, A.; Santala, V.; Roos, C.; Karp, M. Genome sequence of Halanaerobium saccharolyticum subsp. saccharolyticum strain DSM 6643T, a halophilic hydrogen-producing bacterium. Genome Announc. 2013, 1, e00187-13. [PubMed]

77. Ali, M.M.; Zhao, H.; Li, Z.; Maglas, N.N. Concentrations of TENORMs in the petroleum industry and their environmental and health effects. RSC Adv. 2019, 9, 39201-39229. [CrossRef]

78. Makarova, K.S.; Aravind, L.; Wolf, Y.I.; Tatusov, R.L.; Minton, K.W.; Koonin, E.V.; Daly, M.J. Genome of the extremely radiation-resistant bacterium Deinococcus radiodurans viewed from the perspective of comparative genomics. Microbiol. Mol. Biol. Rev. 2001, 65, 44-79. [CrossRef]

79. Fisher, D.I.; Cartwright, J.L.; Harashima, H.; Kamiya, H.; McLennan, A.G. Characterization of a Nudix hydrolase from Deinococcus radiodurans with a marked specificity for (deoxy)ribonucleoside 5'-diphosphates. BMC Biochem. 2004, 5, 7. [CrossRef]

80. Dulermo, R.; Onodera, T.; Coste, G.; Passot, F.; Dutertre, M.; Porteron, M.; Confalonieri, F.; Sommer, S.; Pasternak, C. Identification of new genes contributing to the extreme radioresistance of Deinococcus radiodurans using a Tn5-based transposon mutant library. PLoS ONE 2015, 10, e0124358. [CrossRef]

81. Wakeman, C.A.; Goodson, J.R.; Zacharia, V.M.; Winkler, W.C. Assessment of the requirements for magnesium transporters in Bacillus subtilis. J. Bacteriol. 2014, 196, 1206-1214. [CrossRef] [PubMed]

82. Martinez-Ruiz, F.; Jroundi, F.; Paytan, A.; Guerra-Tschuschke, I.; del Mar Abad, M.; González-Muñoz, M.T. Barium bioaccumulation by bacterial biofilms and implications for Ba cycling and use of Ba proxies. Nat. Commun. 2018, 9, 1619. [CrossRef]

83. Gonzalez-Muñoz, M.T.; Martinez-Ruiz, F.; Morcillo, F.; Martin-Ramos, J.D.; Paytan, A. Precipitation of barite by marine bacteria: A possible mechanism for marine barite formation. Geology 2012, 40, 675-678. [CrossRef]

84. Wackett, L.P.; Dodge, A.G.; Ellis, L.B.M. Microbial genomics and the periodic table. Appl. Environ. Microbiol. 2004, 70, 647-655. [CrossRef] [PubMed]

85. Lee, D.D.; Galera-Laporta, L.; Bialecka-Fornal, M.; Moon, E.C.; Shen, Z.; Briggs, S.P.; Garcia-Ojalvo, J.; Süel, G.M. Magnesium flux modulates ribosomes to increase bacterial survival. Cell 2019, 177, 352-360. [CrossRef] [PubMed]

86. Silver, S.; Phung, L.T. Genes and enzymes involved in bacterial oxidation and reduction of inorganic arsenic. Appl. Environ. Microbiol. 2005, 71, 599-608. [CrossRef]

87. Mohan, A.M.; Bibby, K.J.; Lipus, D.; Hammack, R.W.; Gregory, K.B. The functional potential of microbial communities in hydraulic fracturing source water and produced water from natural gas extraction characterized by metagenomic sequencing. PLoS ONE 2014, 9, e107682. [CrossRef]

88. Zhang, F.; She, Y.-H.; Chai, L.-J.; Banat, I.M.; Zhang, X.-T.; Shu, F.-C.; Wang, Z.-L.; Yu, L.-J.; Hou, D.-J. Microbial diversity in long-term water-flooded oil reservoirs with different in situ temperatures in China. Sci. Rep. 2012, 2, 760. [CrossRef] [PubMed]

89. Ragkousi, K.; Eichenberger, P.; Van Ooij, C.; Setlow, P. Identification of a new gene essential for germination of Bacillus subtilis spores with Ca2+-dipicolinate. J. Bacteriol. 2003, 185, 2315-2329. [CrossRef]

90. Yan, S.; Wu, G. Can Biofilm be reversed through quorum sensing in Pseudomonas aeruginosa? Front. Microbiol. $2019,10,1582$. [CrossRef] [PubMed]

91. Mand, J.; Enning, D. Oil field microorganisms cause highly localized corrosion on chemically inhibited carbon steel. Microb. Biotechnol. 2021, 14, 171-185. [CrossRef] [PubMed]

92. Ma, H.; Ma, S.; Hu, H.; Ding, L.; Ren, H. The biological role of N-acyl-homoserine lactone-based quorum sensing (QS) in EPS production and microbial community assembly during anaerobic granulation process. Sci. Rep. 2018, 8, 15793. [CrossRef] [PubMed]

93. Parsek, M.R.; Greenberg, E.P. Acyl-homoserine lactone quorum sensing in gram-negative bacteria: A signaling mechanism involved in associations with higher organisms. Proc. Natl. Acad. Sci. USA 2000, 97, 8789-8793. [CrossRef] [PubMed]

94. Daniels, R.; Vanderleyden, J.; Michiels, J. Quorum sensing and swarming migration in bacteria. FEMS Microbiol. Rev. 2004, 28, 261-289. [CrossRef] [PubMed]

95. Lin, J.; Cheng, J.; Wang, Y.; Shen, X. The Pseudomonas quinolone signal (PQS): Not just for quorum sensing anymore. Front. Cell. Infect. Microbiol. 2018, 8, 230. [CrossRef] [PubMed]

96. Almblad, H.; Harrison, J.J.; Rybtke, M.; Groizeleau, J.; Givskov, M.; Parsek, M.R.; Tolker-Nielsen, T. The cyclic AMP-Vfr signaling pathway in Pseudomonas aeruginosa is inhibited by cyclic Di-GMP. J. Bacteriol. 2015, 197, 2190-2200. [CrossRef] [PubMed] 
97. Craig, L.; Forest, K.T.; Maier, B. Type IV pili: Dynamics, biophysics and functional consequences. Nat. Rev. Microbiol. 2019, 17, 429-440. [CrossRef] [PubMed]

98. Belas, R. Biofilms, flagella, and mechanosensing of surfaces by bacteria. Trends Microbiol. 2014, 22, 517-527. [CrossRef] 